\title{
The Relationship between Work Motivations and the Performance of Kindergarten Principals in Medan City
}

\author{
Nasriah \\ Universitas Negeri Medan \\ Medan, Indonesia \\ email: nasriahcut@yahoo.co.id \\ Sri Milfayetty \\ Universitas Negeri Medan \\ Medan, Indonesia \\ email: milfayetty@yahoo.com \\ Harun Sitompul \\ State University of Medan \\ Medan, Indonesia \\ email: Prof-runsit@yahoo.co.id
}

\begin{abstract}
The purpose of this study was to determine the relationship between work motivation with the performance of kindergarten principal in Medan City. This research method is survey research with correlation technique, this research population is Kindergarten principal of Medan City. Data collection through instrument, data analysis technique that is correlation and regression. Before the data were analyzed, first tested homogeneity and linearity of regression equation. Result of correlation analysis between work motivation variable on principal performance of Kindergarten. This value give understanding that linkage between work motivations to principal performance of kindergarten is positive, meaning better job motivation kindergarten principal then the better the performance of head of kindergarten. Suggestion should the kindergarten principal can improve its performance, more loyal, and responsible in carrying out its duty.
\end{abstract}

Keywords - work motivation; the performance

\section{INTRODUCTION}

Kindergarten Principal is a functional teachers who are given the task to lead the formal education institution where the learning process or where interaction occurs between teachers who provide lessons with students who receive lessons. The word lead contains a large meaning, namely the ability to move all the resources that exist in a school so that can be utilized optimally to achieve the goals set. In institutional practice, the word lead contains the connotations of moving, directing and others. Mulyasa (in Karwati and Priansa, argues that the success of education in schools is largely determined by the success of the Principal in managing education personnel available in schools, Kindergarten Principal is one of the educational components that have an effect on improving teacher performance [1]. The principal of the Kindergarten is responsible for the administration of educational activities, school administration, coaching of other educators, and the utilization and maintenance of facilities and infrastructure. This becomes important in line with the increasing complexity of task demands to formal educational institutions, which require more effective and efficient employment support. In addition, the development of science and technology, as well as art and culture applied in education in schools also tend to move forward, thus demanding professional mastery. Leadership in an organization is very important. The leader is like a pilot in a flight, the captain in a ship, a driver in a vehicle. A leader must be able to carry safely the passengers to achieve the goal. Motivation work is a requirement that must be possessed by someone in this case is the principal of kindergarten. While the quality of education is a special limitations that have a person to become a head, at the end both these components can be an indicator whether the performance of a kindergarten principal could be high or low. While school achievement is the impact of all generated from the motivation of work, and the performance of a principal. The principal is instrumental in mobilizing the various components in the school so that the process of teaching and learning in school goes well. The principal is an educational leader who has a very big role in developing the quality of education in his school. The growing spirit of harmonious cooperation, discipline as a leader, and highly motivated work so as to demonstrate the quality of leadership performance is good in carrying out its duties. Robbins states that performance is a measure of results which is done by using mutually agreed criteria. The criteria are 
dependent on work-related factors [2]. Work motivation, educational level, teacher's income to school performance are the four components that operationally cannot be separated from one another.

The importance of the principal's work motivation to improve his / her performance so that his education is more qualified. Colquitt, LePine, \& Wesson argue that performance is the value of a set of behaviors that contribute positively or negatively to the goal. Performance has three dimensions: 1) task behavior, 2) moral behavior, and 3) opposing behaviors [3]. Motivation comes from the word motive which is often defined as desire or need. Every individual's attitude and behavior is always based on certain motives. This motive is the beginning of every thought, attitude and human behavior. Meanwhile, Luthans also states that motivation is a process that begins with physiological or psychological deficiencies that drive behavior or incentives intended for purpose or incentive. Lunenburg \& Ornstein, motivation is defined as " those processes within an individual that stimulate behavior and channel it in ways that should benefit the organization as a whole"[4]. The opinion of the above experts concludes that motivation is a strength or encouragement of a person who want to do something activity or display certain behaviors to meet the needs of his life with full attention and perseverance. In this journal only discussed to two variable only, that is variable of work motivation to performance of head of kindergarten in Medan city. So the formulation of the problem to be discussed in this paper is whether the relationship between work motivation and the performance of kindergarten principal in Medan city..

\section{THEORITICAL REVIEW OF USE}

\section{A. Performance}

comes from the word ìto performî which means doing an activity and refining according to its responsibilities with the expected results. Performance is the result that a person reaches the size that applies to the work in question. Newstroom argues that good performance will generate rewards, both in economic, social and psychological form [5]. This means that if the individual has a good character and works then his business will be good so they will get a good performance. Etymologically, performance comes from the word performance (performance).

As revealed by Mangkunegara that the term performance is the performance of the word job performance or actual performance (work performance or achievement actually achieved by someone) that is the work in quality and quantity achieved by an employee in performing their duties in accordance with the responsibility given to it [6]. According to Rivai, the performance of the principal is the actual behavior displayed by a head as a work performance based on established standards and in accordance with his role in school [7]. Headmaster's performance is the ability to carry out work or tasks that have in completing a job the school he leads. Performance is the work of an organization in order to realize strategic goals, customer satisfaction and contribution to the strategic environment.
According to Bernadin, Russell defines performance as the outcome of the hard work of the organization in realizing the strategic goals set by the organization, customer satisfaction and its contribution to the economic development of society [8]. Therefore, performance is a multi-dimensional form of building, so the way it measures varies greatly depending on many factors. There are five factors in the popular performance assessment are: (1) Quality of work, including: accuracy, reality, appearance and output acceptance. (2) Quality of work, including: output and contribution volume. (3) Required supervision, including: advice, direction, and improvement. (4) Presence, including: regulation, reliable and timeliness. (5) Conservation, including: prevention of waste, damage and maintenance of equipment..

\section{B. Motivation}

Kreiter and Kinicki that motivation is one of the factors that will affect performance [9]. Next Qolquitt, LePine, and states that the factors that directly determine a person's performance are called motivation [10]. Kindergarten institutions require a principal who is able to manage and empower principal of kindergarten who able to develop the quality of education, discipline, have a culture, have a high personal ability, conducive, and fun. Initial studies found that the head of kindergarten there who never became a teacher, immediately appointed as headmaster. There are some weaknesses of PAUD in managing education: (1) managerial capability is indicated still not able to direct, guide, and supervise the educator in carrying out his duties; (2) the PAUD principal has not dared to act decisively in fostering an educator who commits an offense to carry out his duties; (3) the qualifications and competence of educators are not suitable the needs of educational institutions; (4) PAUD principal that are less relevant to the present leadership paradigm; (5) The low salary affects the low performance of educators. Then the low performance of headmaster cannot be separated from, work motivation, job satisfaction, inappropriate leadership style, and organizational culture.

According to Winkel the elements included in the motivation are: (a) dedication, dedication in relation to selfdevelopment, sincerity, in carrying out duties well, (b) responsibility, is a manifestation of self in the execution of the task of finishing the job well. This responsibility is a commitment to self, and society, (c) independence, is a belief in doing the tasks assigned and done without being dependent on others. Independence is part of the responsibility that reflects the behavior to work sincerely, unaffected or influenced by others in action, (d) personal satisfaction, is the realization of the expectations and goals to be accomplished in doing the task. This satisfaction is the result of the work achievement, the desire that must be realized [11].

Satisfaction will arise when work or performance has been achieved well based on planning, (e) confidence, self-esteem is respect for what belongs to, what exists as part of personality manifestation, and self-ability, (f) like to work hard, happy to work hard means to have sincerity, sincere intention and willingness to work well, (g) want the best results, the effort that has been done with full preparation and seriousness in doing the task, is expected to achieve optima result. (h) feel 
dissatisfied, the motivation that is inside someone is the beginning to work well. The results obtained can spur to work better and more excited. Performance like this needs to be improved, developed, and recommended not to be satisfied with what has been obtained.

\section{RESEARCH METHODOLOGY}

this research is a quantitative research with correlational research. This research was conducted in Medan City, 2016. The research population was 62 people. The sample was conducted by Cochran formula, with a sample size of 33 people. Sampling is done randomly [12]. Retrieval of data through instrument given to respondent. Instrument given to the respondent first tested the validity and reliability. The preparation of the instruments of the two variables (organizational culture, and principal performance) is done by arranging the instrument grid in which the indicator is determined, the questionnaire number, the form and the number of items. Data analysis techniques are correlation and regression. Before the data are analyzed first tested normality, homogeneity test and linearity regression equation. To test the correlation ( $r$ ) is done by $t$ test.

\section{RESULT OF RESEARCH}

Results of data processing on work motivation obtained the lowest score 92.00 and 105.00 is high score. Average value (mean) is 99.30, median 99.00 and mode 101.00 and the standard deviation is 3, 58. Based on the mean, median and mode values indicate that the frequency distribution of work motivation has distributed data distribution normal. Results of data processing performance of the kindergarten principal obtained the lowest score 81.00 and the highest 98.00. The value of mean is 92.00 , and mode 4.810 . Based on these values indicate that the frequency distribution of principal performance of the kindergarten is relatively normal. Furthermore, the calculation result obtained by the level of tendency of the work motivation variable is high as much as 2 principals of kindergarten $(6,06 \%)$, enough category as 14 head of kindergarten $(42,42 \%), 14$ less head kindergarten (42, $42 \%)$, and low category as much as 3 head of kindergarten ( 9 , $09 \%$ ). Thus it can be concluded that the motivation of head of kindergarten work enough. While the level of tendency of kindergarten principal variable is high as many as 4 people (12, $12 \%)$, enough category 14 people $(42,42 \%)$, less category 6 people $(18,18 \%)$, low category counted 8 people $(24,24 \%)$. Thus it can be concluded that the performance of kindergarten principal in Medan city is categorized enough.

Based on the calculation with chi squared (X2) technique for variables of work motivation and principal performance it was found that X2 counted both variables were 3, 91 for X2 and 1,92 for $Y$, while $X 2$ value of table at $(\mathrm{df}=4$ and 3 with $\alpha$ $=0,05$ ) is 9,94 and 7,81. If compared between value $\mathrm{X} 2$ count and variable $\mathrm{X} 2$ value table, it turns out $\mathrm{X} 2$ count $<\mathrm{X} 2$ table, this means that both variables come from normally distributed population. The homogeneity test of variance in this study was done by Bartlett test. Test criteria if X2 count $<\mathrm{X} 2$ table, then homogeneous variant, and vice versa. The calculation results obtained $\mathrm{X} 2$ count $=7,81<\mathrm{X} 2$ table $=16,92$, so the variant $\mathrm{X} 2$ to $\mathrm{Y}$ is homogeneous. The linearity test of simple regression equation of work motivation data and principal performance of Kindergarten is calculated by $F$ (Anava) test. Criterion, if the value of Fcount $<$ Ftabel or $P$ value 0,05 , it can be said that the linear regression equation and vice versa. Results of data processing obtained Fcount $=0.74$ and Ftabel $=$ 2.32 , so the equation of the line $\mathrm{Y}$ over $\mathrm{X}$ is linear.

Based on hypothesis test of research there is a significant of the relationship between work motivations and the performance of kindergarten principal in Medan City, can be seen in the following table:

Table 1. SUMMARY OF CORRELATION ANALYSIS OF X AND Y

\begin{tabular}{|c|c|c|c|c|}
\hline $\begin{array}{c}\text { Correlat } \\
\text { ion }\end{array}$ & $\begin{array}{c}\text { Correlati } \\
\text { on } \\
\text { Coefficie } \\
\text { nt (r) }\end{array}$ & $\begin{array}{c}\text { coefficient } \\
\text { of } \\
\text { determinat } \\
\text { ion } \\
\left(\mathbf{r}^{2}\right)\end{array}$ & $\boldsymbol{T}_{\text {count }}$ & $\begin{array}{c}\boldsymbol{T}_{\text {table }} \\
\boldsymbol{\alpha}=\end{array}$ \\
\hline$R_{\mathrm{xy}}$ & 0,464 & 0,215 & 2,91 & $\mathbf{0 , 0 5}$ \\
\hline
\end{tabular}

Based on the calculation, obtained coefficient correlation of motivation work attitude entrepreneurships with the performance kindergarten principal in Medan City of 0.464 . Furthermore $\mathrm{t}$ test obtained $\mathrm{t}$ arithmetic $=2.91$ and $\mathrm{t}$ table at $\alpha=$ 0.05 of 2.04. Because $t$ arithmetic $>t$ table, it can be argued that the relationship between work motivation with the performance kindergarten principal is significant. Based on the results of the analysis can be concluded that the motivation of work with the kindergarten principal in Medan has a significant relationship. Thus the research hypothesis that there is a working motivation relationship with the performance of the kindergarten principal proved positive and significant. Coefficient of determination ry is 0,215 , it means that work motivation give contribution to kindergarten principal performance in Medan city equal to $21,5 \%$. Regression analysis results obtained regression equation $\mathrm{Y}=28,694=0.623 \mathrm{X} 2$ and Fcount $=8.498$ where Ftabel $\alpha=0.05$ is 4,160 . Apparently the value Fcount $>$ Ftable value which means very significant. This means that the regression equation can be meaningfully used as a predictor of the performance of kindergarten principal in Medan City.

The result of correlation analysis between work motivation variable $(\mathrm{X})$ on the performance of Kindergarten principal (Y) got correlation coefficient value of Ry2 equal to 0,464 . This value gives the understanding that the correlation between work motivations to principal performance of kindergarten is positive, then the better the performance of kindergarten principal. The magnitude of the relationship of work motivation variable to the performance of kindergarten principal can be known by squaring the value of simple correlation. The result of coefficient of correlation coefficient is simply 0,22 . Statistically this value gives an understanding that approximately 22 percent variation of performance change of kindergarten head is determined by work motivation with regression equation pattern $=28,694+0,623 \mathrm{X}$. This equation gives hazard information every the change of one unit of job motivation scores will result in changes in the performance score of head of kindergarten in Medan City, equal to 0.62 The relationship between work motivation on the performance of kindergarten principal tend to like or give positive impact. Indeed, the motivation of work that means the desire to like or reject. Based on the results of the study is associated with the 
results of analysis and testing of hypotheses that exist in this study, it can be concluded the following: "There is a significant relationship between work motivation with the performance of kindergarten principal means if the work motivation of kindergarten principal better so the performance kindergarten principal in Medan city is also better.

\section{RESEARCH DISCUSSION}

Based on the results and discussion of the above research can be stated that (1) The principal should have a high work motivation in carrying out its performance. (2) Preferably the kindergarten institute in Medan can raise the principal based on the needs of the kindergarten institute. (3) The results such as this research can be used as a consideration for the head of kindergarten in improving their performance, among others: attending workshop seminars, training on leadership, management and trainings related to early childhood. Conducting communication among school principals to increase insight and knowledge to improve the quality of education under their leadership.

Conclusion; Based on the data, the results of the analysis have been presented and the problems of the research have been formulated, it can be concluded that there is a relationship between work motivation and the performance of the kindergarten principal in Medan City.

\section{ACKNOWLEDGMENT}

Thanks to Universitas Negeri Medan, which has given me the opportunity to follow the S3 Studies Program Management
Education and Friend colleagues who continue to provide motivation in the completion of jurnal.

\section{REFERENCES}

[1] Mulyasa. Pengembangan dan Implementasi Kurikulum 2013. Bandung: PT Remaja Rosdakarya, 2013. Pp 38

[2] Robbins, Stephen P. (1996). Essensials of Orgaizational Behavior, New Jersey: Prentice-Hall, pp 124

[3] Colquitt, Jason A., Jeffery A. Lepine \& Michael J. Wesson. "Organizational Behavior : Improving Performance and Commitment in the Workplace". New York: McGraw-Hill Irwin, 2009, pp 57.

[4] Luthans, Fred. Organizational Behavior. Seventh Edition. Singapore: McGraw-Hill International Editions, 1996. pp 201.

[5] John W. Newstroorm. "Organizational Behavior", New York: Mc.Graw Hill, 2007, pp 2009

[6] A.A. Anwar Prabu Mangkunegara, Manajemen Sumber Daya Manusia, Cetakan Ke Tujuh PT. Remaja Rosdakarya, Bandung, 2007, pp 67

[7] Veithzal Rivai, "Manajemen Sumber Daya Manusia Untuk Perusahaan, Cetakan Pertama, Jakarta, PT. Raja GravindoPersada, 2004, pp 309.

[8] Bernadin and Russel, Human Resource Management. New Jersey: Internasional Editions Upper Saddle River, Prentice Hall, 1993, pp 530

[9] Kreitner, Robert dan Angelo Kinicki. "Organizational Behavior, International Edition”, New York: MeGraw-Hill Companies, Inc2003, pp 79

[10] Colquitt, Jason A., Jeffery A. LePine, and Michael J. Wesson. Organizational Behavior. New York: McGraw-Hill, 2011. pp 70

[11] Winkel, S, "Psikologi Pengajaran.” Jakarta: Gramedia, 1996, pp. 94

[12] Cochran, William G. "Sampling Techniques," New Delhi: Eastern Private Ltd, 1977, pp 74 